\title{
The Ethics of DNA Testing at the Border
}

Medha D. Makhlouf

Penn State Dickinson Law, mdm5849@psu.edu

Follow this and additional works at: https://ideas.dickinsonlaw.psu.edu/fac-works

Part of the Immigration Law Commons

\section{Recommended Citation}

Medha D. Makhlouf, The Ethics of DNA Testing at the Border, 46 Am. J.L. \& Med. 253 (2020).

This Article is brought to you for free and open access by the Faculty Scholarship at Dickinson Law IDEAS. It has been accepted for inclusion in Faculty Scholarly Works by an authorized administrator of Dickinson Law IDEAS. For more information, please contact lja10@psu.edu. 


\section{The Ethics of DNA Testing at the Border}

Medha D. Makhlouf ${ }^{\dagger}$

I. INTRODUCTION

II. DNA TESTING IN THE IMMIGRATION CONTEXT

A. Voluntary Participation In DNA Testing

1. Immigration Petitions

2. Reunification of Separated Families in the Summer of 2018

3. Rapid DNA Testing Pilot Project at the Southern Border

B. COMPULSORY DNA COLLECTION

1. Refugee Family Reunification Pilot in East Africa

2. Immigration Detainees

III. PRIVACY RISKS OF EXPANDING DNA SURVEILLANCE

A. UNPREDICTED USES OF DNA DATA

B. PERPETUATION OF INACCURACIES

C. Alienage Differential

D. EXACERBATING RACIAL AND ETHNIC INEQUITIES

E. DATA BREACH

IV. UNIQUE RISKS FOR NONCITIZENS

V. THE SIGNIFICANCE OF THE NEW DNA COLLECTION POLICY

A. The Bioethics Perspective

B. The IMmigration Policy Perspective

VI. CONCLUSION

$\uparrow$ Assistant Professor and Director, Medical-Legal Partnership Clinic, Penn State University - Dickinson Law; Assistant Professor, Department of Public Health Sciences, Penn State College of Medicine. 


\section{INTRODUCTION}

U.S. immigration agencies first began using DNA tests to verify family relationships in $2000 .{ }^{1}$ Little changed about that use of DNA tests in the immigration context until the summer of 2018, when Health and Human Services ("HHS") Secretary Alex Azar announced a plan to use DNA testing to reunite thousands of children and parents who had been separated at the United States-Mexico border in the preceding months and had not yet been reunited. ${ }^{2}$ Since then, the Department of Homeland Security ("DHS") and the Department of Justice ("DOJ") have rapidly expanded DNA collection and analysis in the immigration sphere. ${ }^{3}$ Most notably, in October 2019, the DOJ proposed regulations that would require DNA collection from immigration detainees and storage of their genetic information in the Federal Bureau of Investigation's ("FBI") Combined DNA Index System ("CODIS"), a national DNA database for criminal forensic investigation. ${ }^{4}$ In March 2020, these regulations, largely unchanged, were finalized. ${ }^{5}$

Each of these recent expansions of the use of DNA testing in the immigration context has prompted intense outcry from advocates for immigrants. What is it about this technology-which has revolutionized health care, criminal investigations, and genealogy - that makes it objectionable to use in this context? This Article recounts the history of DNA testing in the U.S. immigration context; describes the privacy risks of expanding DNA surveillance generally and for immigrants, in particular; and summarizes the significance of DOJ's new DNA collection policy for bioethics and immigration law.

\section{DNA TESTING IN THE IMMIGRATION CONTEXT}

Understanding U.S. policy on DNA testing in immigration contexts in the past-and how past usage relates to current and proposed uses-is critical for determining appropriate privacy safeguards as DNA testing and its many uses by the government evolve.

\section{A. Voluntary Participation in DNA Testing}

1. Immigration Petitions

Official guidance on the use of DNA testing for the purpose of verifying family relationships by U.S. immigration agencies was first issued in $2000 .{ }^{6}$ Since that time, U.S. Citizenship and Immigration Services ("USCIS"), a sub-agency of DHS that processes immigration and naturalization applications, has accepted DNA test results as

\footnotetext{
${ }^{1}$ Memorandum from Michael D. Cronin, Acting Exec. Assoc. Comm'r, Immigration \& Naturalization Serv., Guidance on Parentage Testing for Family-Based Immigrant Visa Petitions (July 14, 2000) (on file with the American Immigration Lawyers Association) [hereinafter Cronin Memo].

2Julia Ainsley, U.S. Has Nearly 3,000 Separated Migrant Kids, Will Use DNA to Find Parents, NBC News (July 5, 2018, 4:32 PM), https://www.nbcnews.com/politics/immigration/u-s-has-nearly-3-000separated-migrant-kids-will-n888986 [https://perma.cc/EW2Q-L63D].

${ }^{3}$ See discussion infra Sections II.A.3, II.B.2.

${ }^{4}$ DNA-Sample Collection from Immigration Detainees, 84 Fed. Reg. 56,397 (proposed Oct. 22, 2019) (to be codified at 28 C.F.R.pt. 28).

5DNA-Sample Collection from Immigration Detainees, 85 Fed. Reg. 13,483 (Mar. 9, 2020) (to be codified at 28 C.F.R.pt. 28).

${ }^{6}$ Cronin Memo, supra note 1.
} 
evidence of family relationships in the context of the family-based immigration petition, which is the primary way in which noncitizens legally immigrate to the United States.? Generally, immigration law permits U.S. citizens to petition for the admission of their spouses, children, parents, and siblings, and permits lawful permanent residents to petition for their spouses and children. ${ }^{8}$ DNA testing in the context of family-based immigration petitions is not specifically authorized by statute or regulation, but is described in policy documents for USCIS and the Department of State ("DOS"), which evaluate immigration petitions involving intended beneficiaries located within and outside of the United States, respectively. ${ }^{9}$

The policy and procedure for DNA testing in the context of family-based immigration petitions for intended beneficiaries located within the United States has changed very little since it was established in $2000 .{ }^{10}$ When documentary evidence of a family relationship is unavailable or inadequate, immigration officers have discretion to suggest the DNA test option to petitioners and intended beneficiaries. ${ }^{11}$ DNA testing is voluntary. ${ }^{12}$ Participants are responsible for making necessary arrangements with an accredited laboratory and for the costs. ${ }^{13}$ The results are sent directly to USCIS..$^{14}$ Participants may request a copy of the results from the lab..$^{15}$ Testing laboratories provide results in the form of a degree of certainty of the plausibility of the claimed relationship. ${ }^{16}$ If a DNA test indicates that the plausibility of the claimed relationship is less than $99.5 \%$, it is generally not accepted as proof of relationship. ${ }^{17}$ Immigration officers consider the DNA test results alongside any other evidence submitted; therefore, a DNA test establishing the claimed relationship does not guarantee approval of the petition. ${ }^{18}$

2. Reunification of Separated Families in the Summer of 2018

In October 2017, DHS began implementing a policy of routinely separating immigrant families who attempted to enter the United States from Mexico outside of an official port of entry in order to prosecute the parents for the misdemeanor crime of illegal entry. ${ }^{19}$ In April 2018, the policy became official: DHS's "zero-tolerance" policy

${ }^{7}$ See William A. KANDEl, CONG. ReSEARCH SERV., R43145, U.S. FAMILY-BASEd IMmigration POLICY 1 (2018) (noting that family-based immigration makes up two-thirds of all legal permanent immigration); Cronin Memo, supra note 1.

88 U.S.C. $\$ \$ 1151($ b)(2), 1153(a) (2018).

9U.S. DEP'T OF STATE, 9 Foreign AFFAIRS MANUAL AND HANDBOOK 601.11, DNA TESTING TO VERIFY RELATIONSHIPS (2019); Policy Memorandum, U.S. Citizenship \& Immigration Servs., DNA Evidence of Sibling $\quad$ Relationships 3 (Apr. 17, 2018), https://www.uscis.gov/sites/default/files/USCIS/Laws/Memoranda/2018/2018-04-17-PM-DNA-Evidenceof-Sibling-Relationships.pdf [https://perma.cc/7EAE-6P2D]; Cronin Memo, supra note 1 (describing policy on DNA testing to establish parent-child relationships for family-based immigrant visa petitions involving intended beneficiaries located within the United States).

${ }^{10}$ See Cronin Memo, supra note 1.

${ }^{11} \mathrm{Id}$.

${ }^{12} I d$.

${ }^{13} \mathrm{Id}$.

${ }^{14} I d$.

${ }^{15} \mathrm{Id}$.

${ }^{16} I d$.

${ }^{17} \mathrm{Id}$.

${ }^{18} \mathrm{Id}$.

${ }^{19}$ Jonathan Todres \& Daniela Villamizar Fink, The Trauma of Trump's Family Separation and Child Detention Actions: A Children's Rights Perspective, 95 WASH. L. REV. 377, 380 n.6 (2020). 
directed prosecutors to charge every adult in such circumstances with criminal immigration violations, even if the family expressed a credible fear of returning to their country of origin..$^{20}$ As children cannot be held in criminal detention, zero tolerance required separating these adults from the children with whom they traveled to the border - a secondary goal of the policy that the administration believed would deter immigrant families from Central America from coming to seek asylum in the United States altogether. ${ }^{21}$ Detained immigrant children are housed in facilities operated by the Office of Refugee Resettlement (“ORR"), a sub-agency of HHS. ${ }^{22}$

Criminal proceedings for most of the separated parents concluded in guilty pleas with a sentence of time served. ${ }^{23}$ They were then detained in facilities operated by Immigration and Customs Enforcement ("ICE"), a separate sub-agency within DHS responsible for adult immigration detainees. ${ }^{24}$ The vast majority were not reunited with their children upon their return to ICE custody ${ }^{25}$ Some parents were ultimately released from ICE custody while their immigration cases were pending, and others were deported to their countries of origin without their children. ${ }^{26}$ The media reported stories of prolonged detention in poor conditions, traumatized children, and parents unable to locate or obtain release of their children after release or deportation. ${ }^{27}$

On June 26, 2018, a federal district court directed DHS and HHS to reunify immigrant parents and children who had been forcibly separated upon arriving at the United States-Mexico border. ${ }^{28}$ The litigation revealed significant dysfunction in the administration's planning and execution of its family separation policy, including a failure to properly record the identities and locations of immigrant children in its custody. ${ }^{29}$ This mismanagement prevented DHS and HHS from relying on traditional channels of verifying family relationships in order to comply with the court's order. ${ }^{30}$

Amid this chaos, on July 5, 2018, ORR announced that it would use DNA tests to verify the relationships between detained immigrant children and the adults seeking

${ }^{20}$ See Press Release, U.S. Dep't of Justice, Attorney General Announces Zero-Tolerance Policy for Criminal Illegal Entry (Apr. 6, 2018), https://www.justice.gov/opa/pr/attorney-general-announces-zerotolerance-policy-criminal-illegal-entry [https://perma.cc/M2MK-JZ6Y]. Prior to zero tolerance, adults who expressed a credible fear of return were referred to the asylum system and the criminal charge of illegal entry was dropped. William A. KANDEL, CONG. RESEARCH SERV., R45266, THE TRUMP ADMINISTRATION'S "Zero Tolerance" ImMigration ENFORCEMEnt Policy 1-2, 6 (2019) [hereinafter CONG. ResearCh SERV., R45266].

${ }^{21}$ See CONG. RESEARCH SERV., R45266, supra note 20, at 2. DHS did not publicly acknowledge its policy to separate immigrant children from their parents as a deterrence strategy until May 2018. Caitlin Dickerson, The Youngest Child Separated from His Family at the Border Was 4 Months Old, N.Y. TIMES (June 16, 2019), https://www.nytimes.com/2019/06/16/us/baby-constantine-romania-migrants.html [https://perma.cc/6H85WZBD].

${ }^{22}$ CONG. RESEARCH SERV., R45266, supra note 20, at 2.

${ }^{23}$ See Debbie Nathan, Hidden Horrors of "Zero Tolerance" - Mass Trials and Children Taken from Their Parents, INTERCEPT (May 29, 2018, 10:26 AM), https://theintercept.com/2018/05/29/zero-toleranceborder-policy-immigration-mass-trials-children/ [https://perma.cc/763N-Q4NB].

${ }^{24}$ See id.

${ }^{25}$ See Catherine E. Shoichet, The Next Family Separation Crisis: Finding Hundreds of Deported Parents, CNN (July 27, 2018, 9:35AM), https://www.cnn.com/2018/07/27/politics/deported-parentssearch/index.html [https://perma.cc/B56L-HK38].

${ }^{26}$ See id.

${ }^{27}$ See, e.g., Todres \& Villamizar Fink, supra note 19, at 383; Dickerson, supra note 21; Shoichet, supra note 25 .

${ }^{28}$ Ms. L. v. U.S. Immigration \& Customs Enf't, 310 F. Supp. 3d 1133, 1142-44 (S.D. Cal. 2018).

${ }^{29}$ See id.; Todres \& Villamizar Fink, supra note 19, at 385.

${ }^{30}$ See Ainsley, supra note 2. 
to have the children released into their custody. ${ }^{31}$ Part of ORR's rationale for using DNA tests was the looming court deadline to reunify children with their parents. ${ }^{32}$ Obtaining birth certificates would take too long and ORR deemed information obtained from children about their parents' identity to be "unreliable." ${ }^{33}$ This use of DNA tests was different from prior usage in the immigration context in several ways. First, the U.S. government was directly responsible for forcibly separating families. In family-based immigration petition scenarios, petitioners and intended beneficiaries make the decision to leave family members behind, even if it is under difficult circumstances. ${ }^{34}$ Second, DNA tests were used as the first, and sometimes the sole, basis for determining family relationships; until then, DNA tests had been used to confirm family relationships after documentary evidence had been sought or considered..$^{35}$ Third, DNA tests had never before been deployed on such a mass scale for the purpose of verifying immigrant family relationships. ${ }^{36}$

In the rollout of this unprecedented use of DNA testing in the immigration context, DHS and HHS provided very little information to the public about why they had decided to rely on DNA testing; the type of DNA test that would be performed and the profile generated; how DNA samples and profiles would be stored, used, and destroyed; how long profiles would be retained; and the impact of a non-match on separated family members. ${ }^{37}$ Unsurprisingly, ORR's announcement was widely condemned by ethicists, scientists, and advocates for immigrants. ${ }^{38}$ The sources of condemnation were various, and some critics absolutely opposed the use of DNA tests for this purpose even though such tests could hasten reunification and have been used for decades in other immigration contexts..$^{39}$

\footnotetext{
${ }^{31}$ Press Release, U.S. Dep't of Health \& Human Serv., HHS Is Executing On Its Mission With Care And Compassion (July 6, 2018), https://www.hhs.gov/about/news/2018/07/06/hhs-executing-its-missioncare-and-compassion.html [https://perma.cc/GL5M-DMU6]; Maya Rhodan, Some 3,000 Migrant Kids Are Still Separated from Their Parents. The Trump Administration Is Using DNA Tests to Match Them, TIME (July 5, 2018), https://time.com/5331094/dna-tests-separated-families/ [https://perma.cc/D7DP-QVZ5] (describing Azar's announcement to the press on the day before).

${ }^{32}$ Rhodan, supra note 31.

${ }^{33}$ Ainsley, supra note 2.

${ }^{34}$ See Joanna Dreby, U.S. Immigration Policy and Family Separation: The Consequences for Children's Well-Being, 132 SOC. SCI. \& MED. 245, 250 (2014) (describing how forced parent-child separations due to immigration enforcement cause great anxiety and destabilization for families); id. (noting that parental choices to migrate to the United States without their children affect those children differentially and, typically, less acutely).

${ }^{35}$ Erin N. Oliphant \& Sharon F. Terry, Reuniting Families Using Genetic Testing? , 22 GENETIC TESTING $\&$ MOLECULAR BIOMARKERS 453, 453 (2018).

${ }^{36}$ See Daniella Silva, DNA Tests for Separated Families Slammed by Immigration Advocates, NBC NEWS (July 5, 2018, 10:04 PM), https://www.nbcnews.com/news/us-news/dna-tests-separated-families-slammedimmigration-advocates-n889161 [https://perma.cc/RC3K-43EA].

${ }^{37}$ See Oliphant \& Terry, supra note 35 , at 454 (describing lack of transparency in the collection and storage of genetic information by HHS); Silva, supra note 36 (illuminating question as to necessity of genetic testing for reunification).

${ }^{38}$ See, e.g., Catherine Lee \& Torsten H. Voigt, DNA Testing for Family Reunification and the Limits of Biological Truth, 45 SCI. TECH. \& HuM. VALUES 430, 447 (2020) (introducing the concept of social validity to argue that "DNA testing does not come closer to defining what a true family is."); Nita Farahany et al., Ethical Guidelines for DNA Testing in Migrant Family Reunification, 19 AM. J. BIOETHICS 4, 4 (2019) (discussing the international debate among bioethicists, geneticists, and practitioners over the new HHS policy); Rhodan, supra note 31 (discussing advocates' fury); Opinion, DNA Testing is Not the Way to Reunite Families, BALT. SUN (July 2, 2018), https://www.baltimoresun.com/opinion/readers-respond/bs-ed-rrimmigrant-dna-letter-20180702-story.html [https://perma.cc/6CSB-V746] (opposing HHS policy as geneticists, genetic counselors, and ethicists).

${ }^{39}$ See Farahany et al., supra note 38 at 4-5 (pointing out that DNA testing has long been used in family
} 
On July 10, 2018, Judge Sabraw ordered DHS and ORR to use DNA tests "only when necessary to verify a legitimate, good-faith concern about parentage or to meet a reunification deadline." 40 The order required the government to attempt other established techniques for determining family relationships before using DNA tests, obtain consent from participating adults prior to conducting DNA tests, ensure that the DNA samples and profiles generated from the tests would not be shared with federal agencies outside of HHS, destroy DNA samples and profiles within one week of obtaining a result, forbid contractors performing the DNA tests from retaining samples and profiles, and require contractors to destroy samples and profiles within one week of obtaining a result. ${ }^{41}$

It is unclear, even today, if all of the children who were separated from their parents at the border under the "zero tolerance" policy have been reunited with their parents, due to the inadequacy of DHS and HHS tracking systems. ${ }^{42}$ Although it is unlikely that this or a future administration would implement a family separation policy like the one that drew such popular condemnation in the summer of 2018, immigrant children continue to be detained and separated from their family members at the border. ${ }^{43}$ When the government determines that children would be unsafe in the custody of a parent because of the parent's criminal history, for example, it may decide to take the children into ORR custody. ${ }^{44}$ Or if a child presents at the border with a relative who is not their parent, the child may be separated from them and held in ORR custody until the agency conducts background checks on family members seeking their release. ${ }^{45}$ Therefore, it is still important for ICE to have a thoughtful and comprehensive policy on DNA testing to reunify immigrant family members.

immigration contexts and that DNA testing may reunify families); see also Rhodan, supra note 31 (quoting one advocate calling DNA testing in this context the "grossest violation of human rights").

${ }^{40}$ Order Following Status Conference at 3, Ms. L. v. U.S. Immigration \& Customs Enf't, No. $18 \mathrm{cv} 428$ DMS (MDD) (S.D. Cal. July 10, 2018).

${ }^{41} I d$. at 3 (citing Parties Proposal on Office of Refugee Resettlement Release Process at 7-8, Ms. L. v. U.S. Immigration \& Customs Enf't, No. 18cv428 DMS (MDD) (S.D. Cal. July 9, 2018)).

${ }_{42}^{4}$ See More Than 5,400 Children Split at Border, According to New Count, NBC NEws (Oct. 25, 2019), https://www.nbcnews.com/news/us-news/more-5-400-children-split-border-according-new-count-n1071791 [https://perma.cc/939F-DRE8]. Thousands of other children have been separated from their families either before or after zero tolerance, and many remain in custody. Id.

${ }^{43}$ See Julia Ainsley, Family Separation is Back for Migrants at the U.S./Mexican Border, Say Advocates, NBC NEws (May 15, 2020), https://www.nbcnews.com/politics/immigration/family-separation-backmigrants-u-s-mexican-border-say-advocates-n1208186 [https://perma.cc/VPM2-UBNX] (describing a recently implemented process in which ICE permits parents who are detained with their children to apply for their minor children to be released to family members, sponsors, or ORR while the parents remain in ICE detention); Jeremy Stahl, Why Did the Government Separate This Family? Slate (May 7, 2020), https://slate.com/news-and-politics/2020/05/family-separation-salvador-rosita.html [https://perma.cc/K88RAX69] (stating that more than 1,150 children have been separated from the parents at the border between June 2018 and March 2020).

${ }^{44}$ See Stahl, supra note 43 (noting that family separations are legally permitted in cases of alleged communicable disease and parental fitness as well).

${ }^{45}$ See Riane Roldan \& Alana Rocha, Family Separations Aren't Over. As Many as Five Kids Per Day Are Separated from Their Parents at the Border., TEX. TRIB. (July 12, 2019, 12:00AM), https://www.texastribune.org/2019/07/12/migrant-children-are-still-being-separated-parents-data-show/

[https://perma.cc/Z3U8-8UPZ] (explaining that children are sometimes released from custody into care of a family member); see also Lomi Kriel, The Trump Administration Is Rushing Deportations of Migrant Children during Coronavirus, ProPublica (May 18, 2020), https://www.propublica.org/article/the-trumpadministration-is-rushing-deportations-of-migrant-children-during-coronavirus [https://perma.cc/NHY4WP3C] (explaining the process by which family members of detained children seek their release, which includes a home study and fingerprint checks). 


\section{Rapid DNA Testing Pilot Project at the Southern Border}

After Judge Sabraw's June 2018 order put an end to DHS's family separation policy, the administration became concerned that adult immigrants would seek more lenient treatment by immigration officials by coming to the United States-Mexico border with their or others' children. ${ }^{46}$ At the time, family units with minor children at the border who demonstrated a credible fear of persecution in their native countries were processed differently from adults: They were less likely to be detained than adults traveling without children because of legal limits on the length and conditions of detention for children ${ }^{47}$ and they were permitted to reside and work in the United States while their asylum applications were pending. ${ }^{48}$

In response, DHS formulated a voluntary rapid DNA testing pilot project to verify family relationships for the dual purposes of (1) determining how an otherwise inadmissible claimed family unit should be processed and (2) aiding in the criminal investigation and prosecution of immigrants making false claims about family relationships ${ }^{49}$ The pilot was conducted over a three-day period in May 2019. ${ }^{50}$ In midJune, ICE announced "a 120-day extension of the pilot program and expansion to five additional locations along the southwest border to assess long-term implementation, starting late June [2019]." 51

Concurrent with the expansion of its rapid DNA testing pilot project in June 2019, DHS released a Privacy Impact Assessment ("PIA") analyzing the privacy risks and mitigation efforts related to its use of rapid DNA technology. ${ }^{52}$ The PIA describes the process by which the expanded pilot is being implemented.$^{53}$ If ICE personnel suspect that members of a claimed family unit are lying about their relationship, they can solicit the family members' participation in rapid DNA testing. ${ }^{54}$ A short privacy statement provided to immigrants selected for participation describes

[T] he purpose of the Rapid DNA testing, the legal authority under which DNA is collected, that information related to the collection of DNA (e.g., the existence of a positive or negative match) may be

\footnotetext{
${ }^{46}$ See DeP'T OF HOMEland SEC., PRIVACY IMPACT ASSESSMENT FOR THE RAPID DNA OPERATIONAL USE 1 (2019), https://www.dhs.gov/publication/dhsicepia-050-rapid-dna-operational-use [https://perma.cc/DQ7T-2UYN] [hereinafter PIA FOR RAPID DNA].

${ }^{47}$ Id.; see Stipulated Settlement Agreement, Flores v. Reno, No. CV 85-4544-RJK(Px) (C.D. Cal. Jan. 17,1997 ) (governing the treatment of children in federal custody).

${ }^{48}$ See Hearing on Oversight of Immigration Enforcement and Family Reunification Before the S. Comm. on the Judiciary, 115th Cong. 6 (2018) (statement of Matthew T. Albence, Exec. Associate Director, Enf't \& Removal Operations, U.S. Immigration \& Customs Enf't, Dep't of Homeland Sec.), https://www.judiciary.senate.gov/imo/media/doc/07-31-18\%20Albence\%20Testimony.pdf

[https://perma.cc/Z43E-83VG] (“[C]urrent laws and court rulings which favor the release of family units and [unaccompanied alien children [UACs]] often require the federal government to release illegal alien families and UACs into communities across the United States.").

${ }^{49}$ See PIA FOR RAPID DNA, supra note 46, at 9, 16 ("The DNA is being collected to confirm or refute a claimed biological parent-child relationship. ICE will use the results to identify family unit fraud at U.S. border processing stations.”).

${ }^{50}$ News Release, U.S. Dep't of Homeland Security, U.S. Immigration \& Customs Enf't, ICE Awards New Contract for Rapid DNA Testing at Southwest Border, Expands Pilot Program (June 18, 2019), https:/www.ice.gov/news/releases/ice-awards-new-contract-rapid-dna-testing-southwest-border-expandspilot-program [https://perma.cc/3JFJ-MJAL].

${ }^{51} I d$.

52PIA FOR RAPID DNA, supra note 46, at 1.

${ }^{53} \mathrm{Id}$. at 3-6.

${ }^{54} \mathrm{Id}$. at 4.
} 
shared according to federal law and policy, and that submitting to Rapid DNA testing is voluntary, but that failure to submit to Rapid DNA testing may be taken into account as one factor in ICE's assessment of the validity of the claimed parent-child relationship..$^{55}$

Written consent for the test is obtained from adults on their own behalf and on behalf of any claimed children. ${ }^{56}$ The PIA does not address the risk of coercion and how that might impact an immigrant's ability to meaningfully consent to participate in DNA testing. ${ }^{57}$ Finally, the PIA describes the technological and other limitations on ICE's handling and processing of DNA samples and test results. ${ }^{58}$

The rapid DNA testing pilot represents another shift in the use of DNA analysis: from a tool for reunifying immigrant families to a tool for law enforcement purposes. It is an example of "function creep," defined as "the gradual and sometimes imperceptible expansion of surveillance mechanisms, once in place, for secondary uses beyond those originally intended or contemplated." ${ }^{59}$ A system of surveillance instituted for the purpose of identifying immigrant family units in order to determine their treatment under immigration law is simultaneously used for the purpose of solving unsolved crimes. It is also an example of the criminalization of immigration itself; merely attempting to enter the country makes one an object of scrutiny for law enforcement purposes. For those attempting to enter the country legally, failing to clear any number of procedural hurdles can lead to criminal prosecution. ${ }^{60}$

\section{B. COMPULSORY DNA COLLECTION}

1. Refugee Family Reunification Pilot in East Africa

Historically, DHS and DOS have instituted compulsory DNA testing for only one category of immigrants seeking family-based visas: participants in the U.S. Refugee Admissions Program Priority Three ("P-3") program. ${ }^{61}$ These are the spouses, unmarried children, and parents of people of designated nationalities who entered the United States as refugees or who were granted asylum..$^{62}$ Suspicions of fraud in the P-3 program were the primary driver of the testing policy, which was piloted in 2008 and mandated in $2012{ }^{63}$ Although compulsory DNA tests have not been instituted in other family-based immigration contexts, the possibility of expansion is real: The impetus for the pilot DNA testing policy in the P-3 program was a 2006 recommendation by the USCIS Ombudsman to DHS to issue regulations authorizing the USCIS Director to require DNA tests as evidence of family relationships. ${ }^{64}$

\footnotetext{
${ }^{55} I d$.

${ }^{56} I d$. at 8.

${ }^{57} I d$.

${ }^{58} I d$. at 9.

${ }^{59}$ Anil Kalhan, Immigration Surveillance, 74 MD. L. REV. 1, $69-70$ (2014).

${ }^{60}$ See id. at 25-26.

${ }^{61}$ See Andorra Bruno, Cong. Research SERv., RL31269, Refugee Admissions AND RESETTLEMENT POLICY 7 (2018).

${ }^{62} I d$.

${ }^{63} I d$.

${ }^{64}$ Memorandum from Prakash Khatri, Ombudsman, U.S. Citizenship \& Immigration Servs., to Emilio Gonzalez, Dir., U.S. Citizenship \& Immigration Servs. 1 (Apr. 12, 2006), https://www.dhs.gov/xlibrary/assets/CISOmbudsman_RR_26_DNA-04-13-06.pdf [https://perma.cc/FM32WPRD] (suggesting "a recommendation to accept DNA test results as secondary evidence of family
} 


\section{Immigration Detainees}

Congress authorized the Attorney General to collect DNA from persons in federal custody, including immigration detainees, in the DNA Fingerprint Act of $2005 .{ }^{65}$ The DNA profiles that are generated from this collection are stored in the FBI's DNA database, CODIS. ${ }^{66}$ The collection and storage of DNA information in CODIS is for the purpose of law enforcement identification. ${ }^{67}$

The implementing regulations for the DNA Fingerprint Act mandate the collection of DNA from all persons who are arrested on federal criminal charges and from all "non-United States persons" in immigration detention. ${ }^{68}$ However, the Attorney General has discretion to limit or exempt the collection of DNA by certain agencies. ${ }^{69}$ A special provision permitted the Secretary of Homeland Security to exempt DNA collection from immigration detainees, including circumstances in which "collection of DNA samples is not feasible because of operational exigencies or resource limitations." ${ }^{70}$ To date, DHS has not implemented compulsory DNA collection of immigration detainees who do not have a criminal record, based on this exemption authority. ${ }^{71}$

In October 2019, DOJ proposed regulations that would reallocate the exemption authority for compulsory DNA collection from immigration detainees from the Secretary of Homeland Security to the Attorney General $;{ }^{72}$ a final rule was issued on March 9, 2020..$^{73}$ Although DOJ accurately states that "this rulemaking does not require DHS to expand DNA-sample collection," former Attorney General Jeff Sessions made no secret that this had been the intention since the rulemaking began. ${ }^{74}$ In anticipation of the rule change, DHS began implementing a pilot project to collect DNA from immigrants detained by Customs and Border Protection ("CBP") in the Detroit sector and at the Eagle Pass Port of Entry in southwestern Texas. ${ }^{75}$ The final rule went into effect on April 8, 2020.76

relationship, to grant authority to directors to require DNA testing and to initiate a DNA testing pilot project to study the impact of requiring DNA testing as evidence of family relationship").

${ }^{65}$ See 34 U.S.C. $§ 40702$ (a)(1)(A) (2018); see also DNA-Sample Collection Under the DNA Fingerprint Act of 2005 and the Adam Walsh Child Protection and Safety Act of 2006, 73 Fed. Reg. 21,083, 21,083-84 (proposed Apr. 18, 2008) (to be codified at 28 C.F.R. pt. 28).

6634 U.S.C. $\$ 40702$ (b).

${ }^{67}$ Combined DNA Index System (CODIS), FED. Bureau OF Investigation, https://www.fbi.gov/services/laboratory/biometric-analysis/codis [https://perma.cc/FZF2-3B3J] (last visited Apr. 14, 2020).

6828 C.F.R. § 28.12(b) (2019) (defining "non-United States persons" as "persons who are not United States citizens and who are not lawfully admitted for permanent residence").

${ }^{69} \mathrm{Id}$.

${ }^{70} I d$.

${ }^{71}$ See DeP'T of Homeland SeC., PRIVACy ImPaCt Assessment for the CBP AND ICE DNA COLLECTION 1 (2020) [hereinafter PIA FOR DNA COLLECTION] (citing Letter from Janet A. Napolitano, Sec'y, Dep't of Homeland Sec., to Eric H. Holder, Jr., Att'y Gen. (Mar. 22, 2010)).

72DNA-Sample Collection from Immigration Detainees, 84 Fed. Reg. 56,397, 56,397 (proposed Oct. 22, 2019) (to be codified at 28 C.F.R. pt. 28).

${ }^{73}$ DNA-Sample Collection from Immigration Detainees, 85 Fed. Reg. 13,483, 13,483 (Mar. 9, 2020) (to be codified at 28 C.F.R. pt. 28).

${ }^{74} I d$. at 13,488 .

${ }^{75}$ News Release, U.S. Dep’t of Homeland Security, U.S. Customs \& Border Prot. (Jan. 6, 2020), https://www.cbp.gov/newsroom/national-media-release/cbp-assess-collection-dna-samples [https://perma.cc/M3CN-MUEZ].

${ }^{76}$ DNA-Sample Collection from Immigration Detainees, 85 Fed. Reg. 13,483, 13,483 (Mar. 9, 2020); see Merrit Kennedy, Trump Administration Poised To Start Collecting DNA From Immigration Detainees, NAT'L 


\section{PRIVACY RISKS OF EXPANDING DNA SURVEILLANCE}

As a foundation for analyzing DOJ's justification for expanding DNA collection from immigration detainees, this Part provides an overview of privacy harms related to mass collection and sharing of biometric information by the government, with a focus on potential privacy harms arising from the new policy. Concerns about privacy harms are among the most important reasons for the government to refrain from expanding DNA databases and are often voiced when the government proposes to expand biometrics surveillance on a mass scale. ${ }^{77}$ Increased collection and sharing of DNA information across agencies enhances the government's ability to surveil members of the population ${ }^{78}$ However, policymakers and courts have always balanced the value of individual privacy with other values that are considered socially beneficial. ${ }^{79}$

For example, privacy harms associated with a certain level of government surveillance in order to investigate crimes and protect public safety are generally tolerated. U.S. law enforcement first began using DNA testing to investigate crimes by linking crime scene evidence with the DNA of violent offenders. ${ }^{80}$ DNA profiles in CODIS are stored permanently and can be accessed by law enforcement at any level without consent, suspicion, or a warrant. ${ }^{81}$ Over time, state and federal laws rapidly expanded the list of offenses eligible for DNA collection and profile retention in CODIS, and some jurisdictions began collecting DNA from people who had merely been arrested on suspicion of having committed a crime. ${ }^{82}$

The issue of whether the government may collect DNA from people who have not been convicted of a crime implicates the Fourth Amendment protection against unreasonable search. ${ }^{83}$ Several federal and state courts that initially considered this question reached opposite conclusions. ${ }^{84}$ In 2013, the U.S. Supreme Court upheld Maryland's statute authorizing pre-conviction collection of arrestees' DNA as a reasonable search under the Fourth Amendment, "[i]n light of the context of a valid arrest supported by probable cause" relating to an alleged crime..$^{85}$ The Court considered compulsory DNA collection in this context to be reasonable because (1) it serves important governmental interests related to law enforcement, (2) CODIS provides

PUB. RADIO (Mar. 6, 2020, 5:25 PM), https://www.npr.org/2020/03/06/812940401/trump-administrationpoised-to-start-collecting-dna-from-immigration-detainees [https://perma.cc/QS7R-EX35].

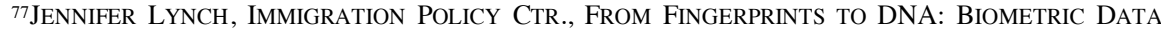
COLLECTION IN U.S. IMMIGRANT COMMUNITIES AND BEYOND 3, 7-8 (2012) (explaining the privacy issues resulting from the expansion of DNA surveillance).

${ }^{78}$ Id. at 9.

${ }^{79}$ See id. at $12-13$.

${ }^{80}$ Elec. Frontier Found., Comment Letter on Proposed Rule for DNA-Sample Collection from Immigrant Detainees (Nov. 12, 2019) [hereinafter EFF Comment].

${ }^{81} \mathrm{LYNCH}$, supra note 77 , at 7-8.

${ }^{82}$ See U.S. DEP'T OF JUSTICE, COMBINED DNA INDEX SySTEM OPERATIONAL AND LABORATORY VULNERABILITIES, 3-6 (2006) (describing the gradual expansion of DNA collection for criminal justice purposes through federal and state legislation).

${ }^{83}$ See LYNCH, supra note 77, at 12 (summarizing Fourth Amendment jurisprudence on biometrics collection).

${ }^{84}$ See, e.g., Henry T. Greely, The Supreme Court and Mandatory Collection of DNA from Arrestees "Stay" Tuned!, Stan. L. SCH. Blogs: L. \& Biosciences Blog (July 22, 2012), https://law.stanford.edu/2012/07/22/the-action-inaction-distinction-before-nfib-v-sebelius/

[https://perma.cc/5F5S-BT8Y] (summarizing court decisions considering the constitutionality of compulsory DNA sampling from people arrested for crimes).

${ }^{85}$ Maryland v. King, 569 U.S. 435, 465-66 (2013). 
adequate privacy protections, and (3) a cheek swab to collect DNA is a minimal intrusion on individual privacy. ${ }^{86}$

In Immigration Surveillance, a seminal article documenting the rise of surveillance mechanisms in immigration enforcement activities, Anil Kalhan adopts the following definition of surveillance: "the systematic monitoring, gathering, and analysis of information in order to make decisions, minimize risk, sort populations, and exercise power." ${ }^{87} \mathrm{He}$ describes in detail the use of four surveillance activities in immigration enforcement: "identification, screening and authorization, mobility tracking and control, and information sharing." 88

In immigration enforcement, biometric identifiers such as fingerprints, facial recognition-ready digital photographs, iris scans, palm prints, hand vein scans, voice prints, and DNA are favored over documentation as more efficient and accurate mechanisms to identify individuals. ${ }^{89}$ They are used to analyze, screen, and authorize noncitizens in a variety of settings unrelated to international travel, including at "local police stations, private workplaces, benefits agencies, universities, [and] health insurers and providers." ${ }^{0}$ Biometric information systems are one of several tools that the government uses to track and control the movement of U.S. citizens and noncitizens across borders ${ }^{91}$ Finally, biometrics information of noncitizens is shared among several government database systems, including systems housed in "intelligence agencies, law enforcement, immigration authorities, international entities, foreign governments, and other institutions, both public and private." ${ }^{92}$

Biometric information about noncitizens-specifically fingerprints, facial recognition-ready digital photographs, and iris scans - are stored in DHS's Automated Biometric Identification System ("IDENT"), which is housed in government-run data centers. ${ }^{93}$ DHS is developing a new cloud-based system, the Homeland Advanced Recognition Technology System ("HART"), which will contain all of the information currently stored in IDENT and will have expanded capacity to store and analyze additional biometric identifiers such as palm prints, scars, tattoos, physical markings, and voices. ${ }^{94}$ Biometric information is linked to machine-readable travel documents such as passports and visas, which incorporate biometric identifiers..$^{95}$ ICE has recently ramped up the routine collection of fingerprints from children in immigration detention, including those held by CBP at or near the border with their parents and those in ORR shelters. ${ }^{96}$

${ }^{86} I d$. at $463-64$.

${ }^{87}$ Kalhan, supra note 59, at 28 (quoting JOHN GILliom \& TORIN MONAHAN, SUPERVISION: AN INTRODUCTION TO THE SURVEILLANCE SOCIETY 2 (2013)).

${ }^{88}$ Id.

${ }^{89}$ Id. at 30 .

${ }^{90} I d$. at 32 .

${ }^{91}$ See id. at 37 (describing complementary information systems used to track movement, including GPS systems, cellular telephone location data, and automated license plate readers).

${ }^{92} I d$. at 39 .

${ }^{93} \mathrm{See}$ id. at 30-31 (noting that IDENT stores information about some U.S. citizens as well, namely those "enrolled in DHS' registered traveler programs or who have adopted children from abroad," or those who were fingerprinted before naturalizing).

${ }^{94}$ See, e.g., Jack Corrigan, Legacy Systems Held DHS' Biometrics Programs Back. Not Anymore., NEXTGOV (Oct. 3, 2019), https://www.nextgov.com/it-modernization/2019/10/legacy-systems-held-dhsbiometrics-programs-back-not-anymore/160347/ [https://perma.cc/4KAX-JQNP].

${ }^{95}$ Kalhan, supra note 59, at 31-32.

${ }^{96}$ See, e.g., Hamed Aleaziz, ICE Is Now Fingerprinting Immigrants as Young as 14 Years Old, BuzzFEEd News (Feb. 6, 2020, 7:42 PM), https://www.buzzfeednews.com/article/hamedaleaziz/ice- 
DOJ justifies its new policy requiring DNA collection from all immigration detainees by describing several governmental interests that parallel the interests served by collection from arrestees and that the Supreme Court relied upon in Maryland v. King: "identification of persons in custody, facilitating safe and secure custody, informing decisions concerning detention and release pending further proceedings, clearing the innocent, and bringing the guilty to justice. ${ }^{97}$ Ensuring public safety is the overarching rationale..$^{98}$

Finally, it is important to note that the title of this Article refers to DNA testing at "the border." By this term, I am referring not merely to a territorial boundary, but to the more nuanced concept in which it is understood in the context of immigration governance.${ }^{99}$ Even after noncitizens have entered and are residing within the country, they are subject to direct and indirect immigration enforcement, which "draws the migration border inward, self-consciously constructing virtual, domestic border checkpoints throughout the country's interior." ${ }^{100}$ Direct enforcement is the initiation of removal proceedings based on unlawful presence or post-entry conduct such as criminal convictions. ${ }^{101}$ Indirect enforcement can occur whenever a public or private actor must verify immigration or citizenship status in order to make an eligibility determination. ${ }^{102}$ This includes many activities of day-to-day life, such as applying for a job, public benefits, or a driver's license; registering for school; seeking health care; renting a home; or buying a bus ticket. ${ }^{103}$ Both types of enforcement have increased dramatically in recent decades and can affect immigrants who have not recently crossed a territorial border. ${ }^{104}$ Post-entry enforcement actions have fueled the growth of immigration detention and will therefore fuel the growth of DNA surveillance of immigrants under DOJ's new policy.

\section{A. UNPREDICTED USES OF DNA DATA}

\footnotetext{
immigration-customs-fingerprinting-refugees-teens [https://perma.cc/LV7V-4X3J]. CBP has discretion to collect fingerprints from noncitizens under the age of 14 "in potentially criminal situations." PIA FOR DNA COLLECTION, supra note 71, at 4 n.12.

${ }^{97}$ DNA-Sample Collection from Immigration Detainees, 85 Fed. Reg. 13,483, 13,487 (Mar. 9, 2020) (to be codified at 28 C.F.R.pt. 28). Regarding international travelers who are being inspected at or near the border, the Fourth Amendment does not provide protection from a routine, suspicion-less, warrantless search, so long as the search is nonintrusive. See United States v. Montoya de Hernandez, 473 U.S. 531, 538 (1985) (describing the border exception, a doctrine that holds that a sovereign's national security interests at the border outweigh the privacy interests of the international traveler); see also DNA-Sample Collection from Immigration Detainees, 85 Fed. Reg. at 13,489.

${ }^{98}$ See DNA-Sample Collection from Immigration Detainees, 85 Fed. Reg. at 13,483 (describing the main legal and policy reasons supporting DNA collection from immigration detainees as the ability to identify guilty and innocent parties); see also id. at 13,487 (summarizing the governmental interests served by DNA collection from immigration detainees as "identification of persons in custody, facilitating safe and secure custody, informing decisions concerning detention and release pending further proceedings, clearing the innocent, and bringing the guilty to justice"); $i d$. at 13,488 (stating that collecting DNA from the broadest class permitted under the law "maximizes [the law's] value in promoting public safety").

${ }^{99}$ See Kalhan, supra note 59, at 59 (describing how immigration surveillance is increasingly "decoupling the territorial border of the United States from... its migration border: the set of boundary points at which nation-states authorize individuals to enter or be admitted, prevent or allow their entry or admission, or subject them to possible expulsion").

${ }_{100} I d$. at 60 .

${ }^{101}$ See id. at $17-22$.

${ }^{102}$ See id. at 23-25.

${ }^{103}$ See id.

${ }^{104}$ See id. at 19.
} 
DNA contains much more information than other biometrics, including information that many people consider sensitive such as "gender, familial relationships, and other hereditary information, race, health, disease history and predisposition to disease, and perhaps even sexual orientation." 105 The potential applications of DNA analysis are infinite and are expanding every day. ${ }^{106}$ Even as the law has struggled to keep pace with these new applications, it can be surmised from recent history that, as technology improves, the role of DNA in immigration and criminal processes will continue to grow.

In its new policy, DOJ seeks to alleviate concerns about privacy harms by characterizing the DNA profiles stored in CODIS as "sanitized "genetic fingerprints,", claiming that they are useful only to identify an individual and cannot be used to "disclose the individual's traits, disorders, or dispositions." 107 However, it is becoming increasingly evident that this "non-coding" DNA contains more information than previously believed and that technological advances will likely enable more information to be mined from the profiles stored in CODIS. ${ }^{108}$

In addition, because DOJ retains DNA samples and not just DNA profiles, it is entirely possible for the government to mine these samples for sensitive information that we know to be linked with DNA. ${ }^{109}$ The sample itself contains information about a person's entire genetic make-up, which is significantly more than and different in kind from the type of biometric information that is currently gathered, as some courts have recognized. ${ }^{110}$ Government access to a person's DNA information goes far beyond serving the purpose of identifying that person. ${ }^{111}$ The combination of interoperable data systems storing biometric information, unlimited data retention times, and little oversight and transparency over the retrieval and use of sensitive biometric information increases the likelihood of function creep. ${ }^{12}$

\section{B. PERPETUATION OF INACCURACIES}

Widespread collection and sharing of DNA information across government agencies can perpetuate inaccuracies that originate from one source. ${ }^{113}$ These inaccuracies can cause the wrong people to be profiled and surveilled, subjecting them to repeated intrusions of privacy in the form of searches and interrogations. ${ }^{114}$ Based on current information-sharing practices designed to protect national security, we know that

\footnotetext{
${ }^{105} \mathrm{LYNCH}$, supra note 77 , at 7.

${ }^{106}$ See Oliphant \& Terry, supra note 35, at 454.

${ }^{107}$ DNA-Sample Collection from Immigration Detainees, 85 Fed. Reg. 13,483, 13,485 (Mar. 9, 2020) (to be codified at 28 C.F.R. pt. 28).

${ }^{108}$ See, e.g., Stephen S. Hall, Hidden Treasures in Junk DNA, SCI. AM. (Oct. 1, 2012), https://www.scientificamerican.com/article/hidden-treasures-in-junk-dna/ [https://perma.cc/X4S9-ND9Y]. ${ }^{109} \mathrm{LYNCH}$, supra note 77 , at 7-8.

${ }^{110} I d$. at 8 (quoting United States v. Kriesel, 508 F.3d 941, 948 (9th Cir. 2007) ("The concerns about DNA samples being used beyond identification purposes are real and legitimate.")).

${ }^{111}$ See, e.g., Daniel I. Morales et al., Opinion, DNA Collection at the Border Threatens the Privacy of All Americans, N.Y. TimeS (Jan. 23, 2020), https://www.nytimes.com/2020/01/23/opinion/dna-collection-borderprivacy.html [https://perma.cc/QT6P-4U39] (suggesting that verification of family relationships and mitigation of future criminal risk are pretexts for the new DOJ policy).

${ }^{112}$ Kalhan, supra note 59 , at 70-71.

${ }^{113} \mathrm{LYNCH}$, supra note 77, at 9; see also Morales et al., supra note 111 ("A comprehensive DNA database may lead law enforcement to lean even more heavily on genetic technology. But forensic genetics can point to the wrong suspect.").

${ }^{114}$ See LYNCH, supra note 77, at 9; see also Morales et al., supra note 111.
} 
existing immigration records are "notoriously inaccurate and out-of-date." 115 For example, thousands of U.S. citizens have been transferred to ICE custody by state and local law enforcement based on inaccurate immigration records. ${ }^{116}$ As this experience shows, we know that when such errors are disseminated across multiple systems and agencies, they can be very difficult to correct. ${ }^{117}$

Even when the information in DNA databases is accurate, those whose DNA is in the system are more likely to be wrongly implicated in a crime. ${ }^{118}$ In a comment opposing the DOJ regulations expanding compulsory DNA testing of immigration detainees, the Electronic Frontier Foundation describes the case of Lukis Anderson, whose DNA was transferred by the paramedics who had treated him to a crime scene where they treated a victim hours later. ${ }^{119}$ Anderson was arrested and charged with murder even though he was in the hospital at the time the murder occurred. ${ }^{120}$ If his DNA had not been in the system, he would not have been wrongly implicated in the crime. While Anderson's DNA was in the state criminal database because of a prior felony charge, immigration detainees' DNA will be entered into CODIS even if they have never been arrested for a crime. ${ }^{121}$ This means that the risk of this type of mistake is disproportionately likely to affect immigrants who have never had any involvement with the criminal justice system.

\section{Alienage DifFERENTIAL}

The new DOJ rule is an example of an alienage differential in privacy under the Fourth Amendment. ${ }^{122}$ The circumstances leading an immigrant to be detained by immigration law enforcement officers are distinct from the circumstances that lead to criminal arrests because, in the vast majority of cases, immigrants in civil detention have not been suspected of committing a crime. ${ }^{123}$ Although there is no link between lack of immigration status and criminality, the new DOJ policy seems to assume that an immigration detainee, like a criminal arrestee, is under heightened suspicion of criminal behavior. ${ }^{124}$ Therefore, the collection of DNA under the new DHS policy represents an "unprecedented shift" from an intrusion on privacy based on conduct to one that is based on status. ${ }^{125}$ In other words, every immigrant is a suspect. Legal experts on immigration

${ }^{115} \mathrm{LYNCH}$, supra note 77 , at 9.

${ }^{116} I d$. at 9 (discussing the Secure Communities program that shares information between state and local law enforcement and immigration agencies).

${ }^{117} I d$. at $10-11$.

${ }^{118}$ EFF Comment, supra note 80 , at 5.

${ }^{119}$ Id.

${ }^{120} \mathrm{Id}$.

${ }^{121}$ See DNA-Sample Collection from Immigration Detainees, 85 Fed. Reg. 13,483, 13,483 (Mar. 9, 2020) (to be codified at 28 C.F.R. pt. 28).

122This characterization derives from the description of a "class differential" in privacy by criminal justice and poverty law scholars, that is, people of different classes have different reasonable expectations of privacy from warrantless government searches and seizures and people from lower economic classes are more likely to suffer intrusions of privacy by the government. See Michele Estrin Gilman, The Class Differential in Privacy Law, 77 BRoOK. L. REV. 1389, 1392-93 (2012) (citing Christopher Slobogin, The Poverty Exception to the Fourth Amendment, 55 FLA. L. REV. 391, 401-05 (2003)).

${ }^{123}$ Growth in ICE Detention Fueled by Immigrants with No Criminal Conviction, TRAC IMMIGRATION (Nov. 26, 2019), https://trac.syr.edu/immigration/reports/583/ [https://perma.cc/F5BG-KH2W] (indicating that only $36 \%$ of individuals in ICE had a criminal conviction).

${ }^{124}$ See DNA-Sample Collection from Immigration Detainees, 85 Fed. Reg. at 13,484 (claiming that "most immigration detainees are held on the basis of conduct that is itself criminal").

${ }^{125}$ EFF Comment, supra note 80 , at 2. 
and genetic privacy recently opined in The New York Times, that "[b]y severing the longstanding prerequisite of prior (alleged) criminal conduct for compelled DNA collection, the government puts us all at risk." 126 They warn that "once you break the norm requiring criminal conduct for inclusion in CODIS, it is difficult to re-establish." 127

\section{EXACERBATING RACIAL AND ETHNIC INEQUITIES}

Black and Latino men are disproportionately represented in U.S. law enforcement biometrics databases, including in CODIS. ${ }^{128}$ Existing racial bias in the criminal justice system has caused Black and Latino men to be unequally targeted by law enforcement for arrest and convicted of crimes. ${ }^{129}$ The new policy would exacerbate this inequity in the criminal justice system by adding a disproportionate amount of genetic information about Latinx people to CODIS. ${ }^{130}$

\section{E. DATA BREACH}

Whenever personal information is stored in a database, it is subject to breach. ${ }^{131}$ DOJ has dismissed concerns about privacy harms in the event of a data breach affecting CODIS. ${ }^{132}$ However, a recent report of the Senate Committee on Homeland Security and Governmental Affairs identified numerous vulnerabilities in the computer networks of federal agencies that hold personal data. ${ }^{133}$ One of the worst federal agency data breaches in recent years was the 2015 Office of Personnel Management breach, which resulted in the disclosure of security clearance data of more than 20 million current and former federal employees, including more than 5.6 million fingerprint records. ${ }^{134}$ Those whose DNA profiles are stored in CODIS therefore face greater privacy risks from unauthorized access to their genetic information than do people who have not been subjected to a DNA test by law enforcement.

${ }^{126}$ Morales et al., supra note 111 .

${ }^{127} I d$.

${ }^{128}$ EFF Comment, supra note 80, at 8 (citing Jason Silverstein, The Dark Side of DNA Evidence, NATION (Mar. 27, 2013), https://www.thenation.com/article/dark-side-dna-evidence/ [https://perma.cc/Y5C4-S7AZ] ("Black individuals made up 40 percent of profiles in CODIS[.]").

${ }^{129}$ See Thomas L. Johnson \& Cheryl Widder Heilman, Racial Disparity in the Criminal Justice System, 58 BENCH \& B. MinN. 29, 29 (2001)

${ }^{130} \mathrm{EFF}$ Comment, supra note 80 , at 8 (noting that the addition of " 750,000 DNA profiles of immigrant detainees annually will undoubtedly further skew the racial disparities apparent in CODIS").

${ }^{131}$ See, e.g., David Lazarus, Cybersecurity Incidents Spark the Call for Encrypted Data, GOVTECH.COM (Oct. 4, 2017), https://www.govtech.com/news/Consumer-Confidential-A-Breach-Too-Far-Encrypt-OurData.html [https://perma.cc/W52E-V75V] (discussing security breaches involving corporate and government databases); id. (“Experts generally acknowledge that it's impossible to keep hackers at bay.").

${ }^{132}$ DNA-Sample Collection from Immigration Detainees, 85 Fed. Reg. 13,483, 13,489 (Mar. 9, 2020) (to be codified at 28 C.F.R. pt. 28) (stating, in response to comments raising this concern, that the DNA information will be "subject to the privacy and use restrictions of CODIS [and] kept in secure storage by the FBI"). The new regulation describes how DNA profiles in CODIS are delinked from personally identifiable information so that unauthorized disclosures of DNA information would not be traceable to individuals. $I d$.

${ }^{133}$ STAFF OF S. COMM. ON HOMELAND SEC. \& GOV'T AFFAIRS: PERMANENT SUBCOMM. ON InVESTIGATIONS, 116TH CONG., REP. ON FEDERAL CYBERSECURITY: AMERICA's DATA AT RISK 7 (2019) (noting that DHS "failed to address cybersecurity weaknesses for at least a decade").

${ }^{134}$ David Alexander, 5.6 Million Fingerprints Stolen in U.S. Personnel Data Hack: Government, REUTERS (Sept. 23, 2015, 11:50 AM), https://www.reuters.com/article/us-usa-cybersecurity-fingerprints/5-6million-fingerprints-stolen-in-u-s-personnel-data-hack-government-idUSKCN0RN1 V820150923

[https://perma/cc/LD55-6MJG] 


\section{UNIQUE RISKS FOR NONCITIZENS}

This Part describes the unique and more immediate risks that noncitizens face from the expansion of DNA surveillance. It is designed to address arguments that expansions of DNA surveillance and data mining are inevitable and will affect citizens and noncitizens alike, and that it is therefore futile to object to this incremental expansion of DNA surveillance. It explains how DOJ's new policy imposes risks on a politically and socially marginalized population.

Deportation for a violation of civil law is a unique risk of heightened biometric surveillance that only noncitizens face. Even prior to the implementation of DOJ's new policy, documented and undocumented immigrants were under heightened surveillance because of existing biometric collection and sharing practices. ${ }^{135}$ DHS's Secure Communities program requires state and local law enforcement agencies to share fingerprint data with ICE in order to determine if they belong to a noncitizen and in order to enable ICE to decide whether to pursue an enforcement action against the person. ${ }^{136}$ With more DNA profiles of noncitizens being added to CODIS under DOJ's new policy, noncitizens face a heightened risk of immigration surveillance in states that authorize DNA collection from arrestees.

When noncitizens are deported, some face discrimination or worse treatment upon return to their native countries. ${ }^{137}$ The United States has entered into data-sharing agreements with other nations that could result in biometric information about immigration detainees being shared with the governments to which they are deported or where they choose to reside after deportation. ${ }^{138}$ Refugees and asylum seekers are particularly at risk if their biometric information is returned to the countries from which they fled. ${ }^{139}$ Foreign governments can request DNA information about their citizens who are immigration detainees through Interpol. ${ }^{140}$ The misuse of DNA information by foreign governments is not a theoretical harm: From 2016 to 2017, the Chinese government collected DNA from nearly 36 million people, primarily Uighurs, an ethnic and religious minority in the country, as a strategy to track the activities of people suspected of not being loyal supporters of the Communist Party. ${ }^{141}$ Uighur Chinese

${ }^{135}$ See Kalhan, supra note 59, at 41-53.

${ }^{136}$ See U.S. DEP'T HOMELAND SEC., IMMigration \& CUSTOMS ENF'T, SECURE COMMUNITIES: A COMPREHENSIVE Plan TO IDENTIFY AND REMOVE CRIMINAL AliENS 1-3 (2009). In 2014, Secure Communities was replaced with a similar program called the Priority Enforcement Program (PEP). Memorandum from Jeh Charles Johnson, Sec'y, Dep't of Homeland Sec., to Thomas S. Winkowski, Acting Dir., U.S. Immigration \& Customs Enf't (Nov. 20, 2014). It was later reinstated by the Trump Administration in 2017. Exec. Order No. 13,768,82 Fed. Reg. 8,799 (Jan. 30, 2017).

${ }^{137} \mathrm{LYNCH}$, supra note 77 , at 3.

${ }^{138}$ See, e.g., DEP'T OF HOMELAND SEC., FACT SHEET: DHS AgreEMENTS WiTH GuATEMALA, HONDURAS, AND El SALVADOR 1 (2019) (explaining that DHS arrangements with Guatemala, Honduras and El Salvador "aim[] to enhance cooperation between DHS and Northern Triangle countries to prevent and combat crime and other threats to public security, by expanding biometric data collection and information sharing").

${ }^{139} \mathrm{LYNCH}$, supra note 77 , at 3.

${ }^{140}$ DNA-Sample Collection from Immigration Detainees, 85 Fed. Reg. 13,483, 13,491 (Mar. 9, 2020) (to be codified at 28 C.F.R. pt. 28). In the Final Rule, the Department of Justice states that, "The United States does not comply with [Interpol] requests [for biometric information] if it believes they are made for oppressive or improper purposes." Id. However, once the information is shared, there is no way for the Department of Justice to control how it is used. See id.

${ }^{141}$ Sui-Lee Wee, China Uses DNA to Track Its People, with the Help of American Expertise, N.Y. TIMES (Feb. 21, 2019), https://www.nytimes.com/2019/02/21/business/china-xinjiang-uighur-dna-thermofisher.html [https://perma.cc/JAD9-LEJL]. 
citizens have received asylum in the United States for past persecution on the basis of ethnicity and religion..$^{142}$ For some, deportation is a death sentence. ${ }^{143}$

Finally, DOJ's new rule exacerbates the criminalization of immigration in the United States. ${ }^{144}$ DOJ states that neither the purpose nor the effect of DNA collection from immigration detainees will be to "stigmatize and vilify migrants and treat them as threats and criminals." 145 It equates DNA collection with other biometric information collection (such as fingerprinting and photographing) without addressing the distinctive privacy harms, discussed earlier, that DNA collection can impose. However, it ignores the larger policy context in which this administration has criminalized immigration by cracking down on prosecutions for immigration violations; ${ }^{146}$ vilifying nonwhite immigrants through harsh rhetoric, ${ }^{147}$ and stigmatizing longtime undocumented residents by rescinding immigration policies intended to integrate them. ${ }^{148}$ Advocates for immigrants blame this toxic combination for an increase in hate-crime violence against Latinx people. ${ }^{149}$

\section{THE SIGNIFICANCE OF THE NEW DNA COLLECTION POLICY}

\section{A. The Bioethics PersPeCtive}

The expansion of DNA surveillance in the immigration context is troubling from the perspective of bioethics in part because it could be the proverbial canary in the coalmine. In a New York Times op-ed, law professors Daniel I. Morales, Natalie Ram, and Jessica L. Roberts characterize DOJ's new policy as "the latest development in a worrying trend of escalating DNA surveillance." 150 They predict, ominously, a dystopian future in which all U.S. residents are subject to compulsory DNA collection: "This new immigration policy moves us toward completion of [a genetic panopticon]: a genetic

\footnotetext{
${ }^{142}$ See, e.g., Andrew McCormick, One Uighur Man's Circuitous Journey to Safety, NATION (Jan. 13, 2020), https://www.thenation.com/article/world/muslim-uighur-china-asylum/ [https://perma.cc/N73M6PD3] (describing one Uighur-native's journey to finding refuge in the United States after facing religious persecution in China).

${ }^{143}$ See, e.g., Sarah Stillman, When Deportation is a Death Sentence, NEw YoRKER (Jan. 8, 2018), https://www.newyorker.com/magazine/2018/01/15/when-deportation-is-a-death-sentence

[https://perma.cc/E9FY-STUL] (recounting cases of "people who had been deported to their deaths or to other harms" in Mexico and Central America).

${ }^{144}$ See Walter A. EWing et al., American Immigration Council, The Criminalization of IMMIGRATION IN THE UNITED STATES 10, 20 (2015).

${ }^{145}$ DNA-Sample Collection from Immigration Detainees, 85 Fed. Reg. 13,483, 13,488 (Mar. 9, 2020) (to be codified at 28 C.F.R. pt. 28).

${ }^{146}$ See id. at 13,485 (noting that "policies favor[] increased prosecution for immigration violations").

${ }^{147}$ See, e.g., Jayashri Srikantiah \& Shirin Sinnar, White Nationalism as Immigration Policy, 71 STAN.L. REV. 197, 198-99 (2019) (recounting Donald Trump's statements disparaging various groups of nonwhite immigrants, including characterizing Mexican migrants as "rapists" and Middle Eastern and Muslim immigrants as terrorists).

${ }^{148}$ See, e.g., Statement from President Donald J. Trump, The White House (Sept. 5, 2017), https://www.whitehouse.gov/briefings-statements/statement-president-donald-j-trump-7/ [https://perma.cc/FR55-8MDA] (ending Deferred Action for Childhood Arrivals).

${ }^{149}$ See, e.g., Adeel Hassan, Hate-Crime Violence Hits 16-Year High, F.B.I. Reports, N.Y. TIMES (Nov. 12, 2019), https://www.nytimes.com/2019/11/12/us/hate-crimes-fbi-report.html [https://perma.cc/W8FRNAR9].
}

${ }^{150}$ Morales et al., supra note 111. 
database that will ultimately encompass anyone within United States borders, including ordinary Americans neither convicted nor even suspected of criminal conduct." 151

While some might disregard such predictions as hyperbolic, there is ample evidence that DOJ is not adequately considering the potential privacy harms of its new policy. In response to concerns that DNA collection from immigration detainees would perpetuate inaccuracies in criminal investigations, DOJ responded that "DNA matches are not taken as conclusive evidence of guilt. Rather, they are used as investigative leads." ${ }^{152}$ DOJ cites its prior rulemaking for the proposition that "an increase in the number of [DNA] profiles . . . 'does not create a significant risk of innocent persons being implicated in crimes."'153 DOJ implicitly dismisses this privacy risk by not addressing when such a risk becomes significant.

Likewise, DOJ fails to recognize the significance of using a prospective risk assessment of criminality for immigrants. Some of the comments submitted in response to DOJ's Notice of Proposed Rulemaking noted that DNA-sample collection of initial entrants to the United States would not serve many of the purported governmental interests relating to public safety because "initial entrants ... cannot have previously committed crimes within the United States, so there could not be crime-scene DNA evidence that would match to their DNA profiles." ${ }^{154}$ DOJ defended its policy by stating inter alia that "the benefits of DNA-sample collection include the creation of a permanent DNA record that may match to DNA evidence from a later crime, if the detainee remains in or later reenters the United States and commits such a crime." 155 DOJ invoked the purpose of prospective risk assessment again in response to comments criticizing the permanent retention of immigration detainee DNA profiles in CODIS. ${ }^{156}$

Finally, DOJ does not acknowledge a problem with the disparate impact that DNA collection from immigration detainees will have on ethnic minorities. It simply states that the regulation is neutral with respect to national origin, race, ethnicity, and other demographic characteristics. ${ }^{157}$ It also states that "[t]he ethnic and racial proportions in the DNA databases parallel the representation of demographic groups among the persons from whom DNA samples are collected," without acknowledging how racial and ethnic profiling can play a role in determining who ends up in immigration detention..$^{158}$

\section{B. The Immigration Policy Perspective}

${ }^{151} I d$

${ }^{152}$ DNA-Sample Collection from Immigration Detainees, 85 Fed. Reg. at 13,490

${ }^{153} \mathrm{Id}$. at 13,490 (citing DNA-Sample Collection and Biological Evidence Preservation in the Federal Jurisdiction, 73 Fed. Reg. 74,932, 74,937 (Dec. 10, 2008) (to be codified at 28 C.F.R. pt. 28)).

${ }^{154} I d$. at 13,488 .

${ }^{155} I d$. (emphasis added).

${ }^{156} I d$. at 13,491 ("CODIS's functions. . . . also include creating a permanent DNA record for the individual, to which a match may result if he later commits a murder, rape, or other crime and DNA from that offense is searched against CODIS. The latter critical function would be lost if DNA profiles were expunged[.]").

${ }^{157}$ See id. at 13,489-90.

${ }^{158}$ Id. at 13,490 . 
In this time of extreme immigration policymaking that has included increasing workplace immigration enforcement raids, ${ }^{159}$ family separations, ${ }^{160}$ the "remain in Mexico" policy for asylum seekers, ${ }^{161}$ kids in cages, ${ }^{162}$ the Muslim ban, ${ }^{163}$ and the change in public charge policy, ${ }^{164}$ it is fair to ask: Why does the DOJ's new policy pertaining to DNA collection of immigration detainees matter?

For U.S. citizens, there is a self-interested reason to pay attention to how the new policy is implemented: We may be next in line for compulsory DNA collection. Beyond this, however, the new policy matters because it is another attempt by this administration to dehumanize immigrants. Even if it seems less degrading than some of the policies listed above, it is part of this administration's broader agenda to criminalize immigration through reliance on false claims. For example, shortly after winning the 2016 election, President-Elect Donald Trump stated his intention to deport or incarcerate two or three million undocumented immigrants "that are criminal and have criminal records, gang members, drug dealers." ${ }^{65}$ The estimate blatantly misrepresents the actual number of undocumented immigrants with criminal convictions. ${ }^{166}$

Likewise, DOJ claims that ensuring public safety is the overarching rationale of its new DNA collection policy. ${ }^{167}$ However, DOJ fails to provide any evidence that its new rule will increase public safety. ${ }^{168}$ First, DHS acknowledges in a PIA for the new DNA collection policy that "it is unlikely that CBP or ICE would be able to use a DNA profile match for public safety or investigative purposes prior to either an individual's removal to his or her home country, release into the interior of the United States, or transfer to another federal agency" because of the time it would take for the FBI to

${ }^{159}$ See Michelle Hackman, Workplace Immigration Inquiries Quadruple Under Trump, WALL ST. J. (Dec. 5, 2019, 8:00 AM), https://www.wsj.com/articles/workplace-immigration-inquiries-quadruple-undertrump-11575550802 [https://perma.cc/9TP8-Z6Y5]; Sarah Ruiz-Grossman, ICE Dramatically Increased Workplace Arrests of Undocumented Immigrants in 2018, HUFFINGTON POST (Dec. 12, 2018), https://www.huffpost.com/entry/ice-immigration-arrests-work-undocumentedimmigrants_n_5c105b3fe4b0ac537179c247 [https://perma.cc/73RQ-KLEU].

${ }_{160}$ Miriam Jordan, Family Separations May Have Hit Thousands More Migrant Children Than Reported, N.Y. Times (Jan. 17, 2019), https://www.nytimes.com/2019/01/17/us/family-separation-trumpadministration-migrants.html [https://perma.cc/LTA8-56L9].

${ }^{161}$ Adam Liptak \& Zolan Kanno-Youngs, Supreme Court Revives 'Remain in Mexico' Policy for Asylum Seekers, N.Y. TIMES (Mar. 11, 2020), https://www.nytimes.com/2020/03/11/us/supreme-court-mexicoasylum-seekers.html [https://perma.cc/FNT5-XHJT].

${ }^{162}$ Dara Lind, The Horrifying Conditions Facing Kids in Border Detention, Explained, Vox (June 25, 2019, 1:10 PM), https://www.vox.com/policy-and-politics/2019/6/25/18715725/children-border-detentionkids-cages-immigration [https://perma.cc/B72G-YLYE].

163Johnathan Lemire et al., White House Considering Dramatic Expansion of Travel Ban, ASSOCIATED PRESS (Jan. 11, 2020), https://apnews.com/753968e412fab06e6fb8180e7ac98d47 [https://perma.cc/AWK8ATXZ].

${ }^{164}$ Press Release, U.S. Dep't of Homeland Security, DHS Implements Inadmissibility on Public Charge Grounds Final Rule (Feb. 24, 2020), https://www.dhs.gov/news/2020/02/24/dhs-implements-inadmissibilitypublic-charge-grounds-final-rule [https://perma.cc/S7NB-69C4].

${ }^{165}$ Louis Nelson, Trump: Criminals Will Be Deported First, Politico (Nov. 13, 2016, 12:08 PM), https://www.politico.com/story/2016/11/donald-trump-immigrants-criminals-231293 [https://perma.cc/4YPR-LUQU].

${ }^{166}$ See Muzaffar Chishti \& Michelle Mittelstadt, Unauthorized Immigrants with Criminal Convictions: Who Might Be a Priority for Removal?, MigRATION POL'Y InST. (2016), https://www.migrationpolicy.org/news/unauthorized-immigrants-criminal-convictions-who-might-bepriority-removal (estimating that 820,000 unauthorized immigrants living in the United States in 2015 had criminal convictions).

${ }^{167}$ DNA-Sample Collection from Immigration Detainees, 85 Fed. Reg. 13,483, 13,485 (Mar. 9, 2020) (to be codified at 28 C.F.R. pt. 28).

${ }^{168}$ See EFF Comment, supra note 80, at 1. 
process a DNA sample. ${ }^{169}$ Second, studies of DNA databases in the United States and European countries show that merely increasing the number of profiles stored does not correlate with improved efficacy in crime-solving. ${ }^{170}$ Third, several recent analyses have debunked the belief that unauthorized immigration is linked with criminality. ${ }^{171}$ From an immigration policy perspective, it is important to push back on every new policy that is based on false and dehumanizing information about immigrants.

\section{CONCLUSION}

DHS's new piloted DNA collection from immigration detainees represents a significant expansion of DNA surveillance in the United States. The new policy will have the practical effect of adding millions of DNA profiles of noncitizens to CODIS. ${ }^{172}$ More fundamentally, it is contributing to a transformation of the norms around collection and retention of genetic information by the government-namely those that justified retention of genetic profiles in CODIS based on an individual's connection to criminal activity. It can be expected that norm shifting around DNA surveillance of noncitizens will spill over to citizens as well.

As this administration engages in unprecedented uses of DNA collection from immigrants, it must anticipate and address ethical concerns that arise from its actions. So far, DHS and DOJ have failed to engage in careful, deliberative, and measured policymaking around recent expansions of DNA testing in the immigration contextwhether it involves DNA testing for family reunification purposes or for broader "public safety" purposes. ${ }^{173}$ More robust privacy protections around DNA collection from immigrants would not only better protect the interests of participants, but would also establish the legitimacy of DNA analysis in immigration processes by improving transparency, efficiency, and accessibility. ${ }^{174}$ As we become increasingly aware of the limits of our knowledge with respect to future uses of DNA information, it is crucial to take a measured, proportional approach to the use of DNA tests in immigration contexts.

${ }^{169}$ PIA FOR RAPID DNA, supra note 46, at 3.

${ }^{170}$ EFF Comment, supra note 80, at 3-4 (noting that increased collection of DNA samples from crime scenes is more strongly related to crime-solving than adding profiles to DNA databases) (citations omitted). DOJ acknowledges, in the Final Rule, that both types of information are necessary in order for CODIS to operate effectively. DNA-Sample Collection from Immigration Detainees, 85 Fed. Reg. at 13,488.

${ }^{171} \mathrm{See}$, e.g., MichelangELO LANDGRAVE \& ALEX NOWRASTEH, CATO INST., CRIMINAL IMMIGRANTS IN 2017: THEIR NUMBERS, DEMOGRAPHICS, AND COUNTRIES OF ORIGIN 7 (2019) (finding that undocumented immigrants are less likely to be incarcerated than the general population); ALEX NOWRASTEH, CATO INST., CRIMINAL IMMIGRANTS IN TEXAS: ILLEGAL IMMIGRANT CONVICTION AND ARREST RATES FOR HOMICIDE, SEX CRIMES, LARCENY, AND OTHER CRIMES 2-3 (2018) (finding that undocumented immigrants were convicted of fewer crimes than native-born Texans); Michael T. Light \& Ty Miller, Does Undocumented Immigration Increase Violent Crime?, 56 CRIMINOLOGY 370, 370 (2018) (finding that undocumented immigration is not associated with increases in violent crime); Anna Flagg, Is There a Connection Between Undocumented Immigrants and Crime?, MARShall PROJECT (May 13, 2019, 5:00 AM), https://www themarshallproject.org/2019/05/13/is-there-a-connection-between-undocumented-immigrantsand-crime [https://perma.cc/6PLL-VWVY]; Michael Maciag, The Mythical Link Between Immigrants and High Crime Rates, GOVERNING (Mar. 2, 2017), https://www.governing.com/topics/public-justice-safety/govundocumented-immigrants-crime-pew.html [https://perma.cc/XV39-RJYU] (finding similar rates of violent crime and lower rates of property crime in metropolitan areas with larger numbers of undocumented residents).

${ }^{172}$ Abigail Hauslohner, U.S. Immigration Authorities Will Collect DNA from Detained Migrants, WASH. PosT. (Mar. 6, 2020, 2:59 PM), https://www.washingtonpost.com/immigration/us-immigration-authoritieswill-collect-dna-from-detained-migrants/2020/03/06/63376696-5fc7-11ea-9055-5fa12981bbbf_story.html [https://perma.cc/3JHG-4TDA].

${ }^{173}$ See Llilda P. Barata et al., What DNA Can and Cannot Say: Perspectives of Immigrant Families About the Use of Genetic Testing in Immigration, 26 STAN. L. \& POL'Y REV. 597, 600 (2015).

${ }^{174} I d$. at $632-633$. 
This Article has described the most ethically troubling privacy harms arising from widespread DNA surveillance of immigrants. It amounts to a call for action to advocates, policymakers, and scholars with expertise in genetic privacy, bioethics, or immigration to ensure that regulation of DNA collection and analysis in the immigration context is guided by the principles of necessity and proportionality. 